\begin{tabular}{llllllll}
\hline $\mathrm{A}$ & $\mathrm{R}$ & $\mathrm{T}$ & $\mathrm{Y}$ & $\mathrm{K}$ & $\mathrm{U}$ & $\mathrm{E}$ & $\mathrm{Y}$
\end{tabular}

PIOTR GUZOWSKI

Instytut Historii i Nauk Politycznych Uniwersytetu w Białymstoku (Institute of History and Political Sciences, University of Bialystok)

\title{
DEMOGRAPHIC CONDITIONS OF THE FUNCTIONING OF PEASANT FAMILIES AT THE TURN OF THE MIDDLE AGES
}

\section{Introduction}

Studies on the historical demography of families in the pre-industrial period usually concentrate on early modern times, and in the Polish context they do not go back earlier than the 17th century. The main reason for this is the lack of primary sources; status animarum lists, registers of poll taxes (Pol. pogtówne) and hearth taxes (Pol. podymne), as well as Parish registers and population lists only began appearing in the early 17 th century, although the quality and quantity of the surviving materials increased in the next century. A notable exception is the work undertaken by Anna Kamler and Andrzej Wyczański who based their studies (also demographic) of peasant families at the turn of the Middle Ages on village court records. The aim of this article is to present the state of research with regards to this issue and to demonstrate the possibilities of using such judicial source to carry out a demographic analysis of peasant families in the 15th and 16th centuries.

\section{State of art}

Although Anna Kamler's (née Izydorczyk) article was published nearly 30 years ago, it is still a major study of the demography of peasant families in the late Middle Ages and Early Modern era. The author raises issues such as marital strategies (territorial choice of spouses), the economic base for the future family's existence (the bride's dowry; the inheritance system), and the size and structure of the family. With regards to marital strategies, Anna Kamler concluded that: (1) the vast 
majority of marriages were concluded within the newly-wed's village; (2) the daughters of peasants found spouses outside the family village far more frequently than did sons; (3) the distance between the new family's home and the original family usually ranged from between 5 and $30 \mathrm{~km}$, which mean that marriages were mostly concluded within one parish. The decision to marry from outside one's home village was usually due to factors such as a large number of children (the more children, the greater the probability that one of them would find their spouse outside the family village), the parents' economic status (the smaller the daughters' dowry or sons' property, the more marriages were concluded outside the family village), or the village's geographical location (with particular importance being ascribed to the proximity of a town/city). Analyzing the size and structure of the families of full-holders (Pol. kmiecie) and smallholder peasants, Anna Kamler estimated that the average family consisted of 6-7 members, whereas landless lodgers' families were less numerous, consisting usually of 4 members. In the entire peasant population, $84 \%$ of the families had children, but the most affluent families were those of the village elite, i.e. village leaders, millers, innkeepers, and full-holders. Approximately three children in families with offspring reached adulthood (2.8). ${ }^{1}$

In her further studies, Kamler concentrated on peasant hired labour in the early modern period, ${ }^{2}$ however, over the next 20 years, historians largely neglected the issue of late-medieval and 16th-century peasant families. It was Kamler's former supervisor, Professor Andrzej Wyczański who again began writing about peasant families. In his attempt to explain the mass phenomenon of so-called 'empty farms' (Pol. pustki) (abandoned peasant farms), he put forward the hypothesis that it was caused by the short duration of Polish peasants' economic activity.

In two of his articles, Professor Wyczański suggested that the average length of a typical peasant's economic activity was 18-19 years. The average peasant began his independent economic activity only after having inherited his father's farm, which usually coincided with establishing his own family, at the age of 25 or so. This meant that on the peasant's death, his farm could not immediately be taken over by his eldest son, who was at the most 18 years old and therefore too young to assume control over his inheritance. Professor Wyczański

${ }^{1}$ A. Izydorczyk, "Rodzina chłopska w Małopolsce w XV i XVI wieku”, in: Społeczeństwo staropolskie, vol. 3, Warszawa 1983, pp. 7-27.

${ }^{2} \mathrm{~A}$. Kamler, Chtopi jako pracownicy najemni na wsi małopolskiej $w$ XVI i pierwszej połowie XVII wieku, Warszawa 2005. 
attempted to confirm his hypothesis by comparing the situation of peasants with the practices followed by the inhabitants of 16th-century Kraków, and in particular, members of the goldsmiths' guild. Only 20 of the 91 goldsmiths passed their workshops on to their sons, and in nine cases the workshops were inherited by the goldsmiths' sons-in-law. In $78 \%$ of the cases, the direct line of succession was broken and the workshops were not inherited by the goldsmiths' direct heirs. ${ }^{3}$

In their studies into peasant families, both Wyczański and Kamler relied on village court records, while noting the potential advantages of making use of this type of source in a typical demographic analysis.

The appearance of village court records is connected with the promulgation of German law in Polish lands and to the emergence of the institution of local government headed by a village leader (Latin: scultetus; Polish: soltys, German: Schultze) or, in later times (following the repurchase of the hereditary office and property of sottys by village owners), by a special administrator called the wójt (Latin: advocatus, Polish - wójt; German: foyt), chosen by the village owner. Together with peasant aldermen, the sottys had judicial functions in the village. ${ }^{4}$ Over $70 \%$ of the village court rolls deal with land transfers as well as containing information about rents, wills, matters of inheritance, loans and liens, criminal and moral cases (thefts and accusations of witchcraft), and disputes between neighbours. ${ }^{5}$ The majority of the 200 or so surviving court rolls come from the Little Poland and Red Ruthenia regions. Excerpts from these documents were edited and published in 1921 by Bolesław Ulanowski, ${ }^{6}$ whose work became of interest to legal historians. Several court rolls were later published in full; ${ }^{7}$ however,

${ }^{3}$ A. Wyczański, "Powrót do dyskusji o łanach pustych", in: Celem nauki jest człowiek... Studia z historii społecznej ofiarowane H. Madurowicz-Urbańskiej, Kraków 2000, pp. 347-353; id., "O dawnej rodzinie w Polsce i Europie”, in: M. Koźmiński (ed.), Cywilizacja europejska. Eseje i szkice z dziejów cywilizacji i dyplomacji, Warszawa 2010, pp. 149, 163.

${ }^{4}$ S. Grodziski, "Księgi sądowe wiejskie (Zasięg terytorialny i geneza)", Czasopismo Prawno-Historyczne, 12, 1960, pp. 85-139; L. Łysiak, "W sprawie genezy ksiag sądowych wiejskich", Czasopismo Prawno-Historyczne, 14, 1962, pp. 175-194. S. Grodziski, "W sprawie genezy ksiag sądowych wiejskich (po raz drugi)", Czasopismo Prawno-Historyczne, 15, 1963, pp. 293-297.

${ }^{5}$ J. Słowiński, "Kancelarie wsi małopolskich od końca XIV do schyłku XVIII wieku”, Studia Źródtoznawcze, 31, 1990, p. 26.

${ }^{6}$ Starodawnego Prawa Polskiego Pomniki, vols. 11-12: Księgi sqdowe wiejskie, vols. 1-2, ed. B. Ulanowski, Kraków 1921.

${ }^{7}$ Katalog małopolskich ksiag sqdowych wiejskich XV-XVIII wiek, ed. T. Wiślicz, Warszawa 2007. 
most village court rolls have survived as manuscripts, some in very poor condition. ${ }^{8}$

Both the methodology applied by Kamler and Wyczański, and the conclusions they drew could be improved and modified based on further studies into the contents of the village court rolls. For instance, although Anna Kamler' studies were innovative in the Polish context, as well as internationally, she conducted them without applying the conceptual apparatus of historical demography, and the number of families she managed to reconstruct was insufficient for a statistical analysis. The data presented by Andrzej Wyczański are based only on a sample of an unidentified size of village aldermen. For the purposes of the present article, direct incentive and inspiration came from reading Zvi Razi's work Marriage and Death in a Medieval Parish: Economy, Society and Demography in Halesowen $1270-1400^{9}$ in which, in order to reconstruct medieval English peasant families, the author used manor court rolls which are much richer in content than Polish village court records but which have a similar function, i.e. that of ordering ownership within feudal estates. Therefore, the methodology applied in the English publication was also used to analyze the records of one Polish village court. Such sources have not been used in Polish demographic studies before. Besides, Polish historical demographers have not previously been interested in studying 15 th- and 16th-century peasant families and this article aims at drawing their attention to this engrossing subject.

\section{The Village of Trześniowa}

The subject of this study is one of the oldest and most detailed books pertaining to Polish village court records - from the village of Trześniowa (1409-1609), edited by Helena Polaczkówna. ${ }^{10}$

${ }^{8}$ Duplicates of most of them are in the possession of the Library of the Department of Polish Legal History at the Jagiellonian University (Biblioteka Katedry Historii Prawa Polskiego Uniwersytetu Jagiellońskiego) - see: I. Dwornicka, "Teki Adama Vetulaniego", Rocznik Biblioteki PAN w Krakowie, 44, 1999, pp. 77-81.

${ }^{9}$ Z. Razi, Life, Marriage and Death in a Medieval Parish. Economy, Society and Demography in Halesowen 1270-1400, Cambridge 1980; more on English demographic studies on the Middle Ages, see: P. Guzowski, "Metody badań demograficznych społeczeństw średniowiecznych - perspektywa angielska", Przeszłość Demograficzna Polski, 28, 2007, pp. 7-25.

${ }^{10}$ Najstarsza księa sqdowa wsi Trześniowej 1419-1609, ed. H. Polaczkówna (further referred to as Trześniowa), Lwów 1923. 
Situated in the Sanok land, the royal village of Trześniowa (also Trześniów) was pledged as collateral in 1419 and throughout the entire period under study it remained in the hands of representatives of various noble families - the Pstroskis, Szafrots, Kmits, Dolinskis, Radwans and Derszniaks. ${ }^{11}$ Its size is documented in early 16th-century taxation lists which have survived until today - in 1507, 12 mansi of land, a mill, and an inn were taxed in Trześniowa. ${ }^{12}$ In the following years, the acreage of taxed land increased to 13 mansi and remained at this level until at least $1567 . .^{13}$ Towards the close of the 16th century, the size of taxed land fell to 9 mansi in 1579 and $1589 .{ }^{14}$ The village's social structure was quite diversified, with 34 household heads being registered in $1552 .{ }^{15}$ Apart from full-holders, the lists dating from 1579 and 1589 confirmed the presence in the village of 6 smallholders and 10-11 lodgers. ${ }^{16}$ Unfortunately, owing to the fact that there is no village inventory dating from the period under investigation, it is not possible to determine the property structure of full-holders inhabiting the village; however, it could be assumed that the social importance of particular household heads, which could be traced by analyzing the composition of the judicial bench, to some degree reflected the material status of its members.

The names and surnames of the villagers testify to their Polish roots, although migrants from a different ethnic circle, from outside the Carpathian Mountains, can also be found within the community, which is confirmed by their nicknames such as Mikołaj the Bohemian or Bohemus, Jan Węgrzyn (Pol. "Węgry" - Eng. "Hungary"), Maciej Słowak (Pol. "Słowak" - Eng. "Slovak"). Also individuals bearing Ruthenian names appear sporadically - e.g. Hrehor, Fedor, and Jurek.

Until the late 16th century the village belonged to the Catholic parish of Jasionowo, although court records from before 1430 mention plans to build a church in Trześniowa. ${ }^{17}$ The chapel was only erected

${ }^{11}$ A. Fastnacht, Stownik historyczno-geograficzny ziemi sanockiej w średniowieczu, part. 3, Kraków 2002, pp. 19-26.

${ }^{12}$ Central Archives of Historical Records in Warsaw (Archiwum Główne Akt Dawnych w Warszawie; further referred to as AGAD), Archiwum Skarbu Koronnego (further referred to as ASK) I, 20, p. 49v.

${ }^{13}$ AGAD, ASK I, 20, p. 705. Our picture of the unchanging acreage of farms belonging to peasants was certainly also influenced by the system of tax records, based on the so-called old bills.

${ }^{14}$ AGAD, ASK I, 17, p. 552; AGAD, ASK I, 20, p. 918v.

${ }^{15}$ AGAD, ASK I, 21, p. 908v.

${ }^{16}$ AGAD, ASK I, 17, p. 552; AGAD, ASK I, 20, p. 918v.

${ }^{17}$ Trześniowa, no. 20. 
in 1592, when the owners of the estates (the Błoński family) turned the Jasionowo Catholic church into a Calvinist church, and the Catholic parish priest moved to Trześniowa. ${ }^{18}$

The core of the present demographic analysis is a database which lists all the individuals appearing in the court records. The database contains over 1,500 records, including information such as the name, surname/nickname, place of origin, function performed in local government or the village court, information about parents, siblings, spouses and children, as well as case numbers and the dates under which particular individuals appear in the court roll.

Village courts were not permanent institutions, but were convened by the soltys or wojt when the need arose (Lat. iudicium banitum). Not all the cases they dealt with were recorded in the court roll because the peasant had to pay an appropriate fee for a case to be registered. ${ }^{19}$ Therefore, the majority of cases pertain to property transfers, although they also contain some general matters pertaining to the functioning of the community or even personal matters concerning particular household heads. The oldest book of court records from Trześniowa includes 1,542 records dating from the period between 1419 and 1609, which means that on average about eight records were made annually, although there are also years in which no records were entered at all. ${ }^{20}$ The largest number of records (37) was made in 1550 . The notes were usually made in the opening and closing months of the year (from November to December), although the transactions themselves could well have occurred earlier. ${ }^{21}$ In the period of time being studied, the average number of court records in the years in which they were entered into the court roll increased from 6.5 in the first half of the 15 th century, to 8 in the second half of the century, and 11 in the next century.

The nature of the source and the method of note taking are the reasons why court rolls should be treated with caution when used as the bases for demographic research. The first problem concerns their incompleteness. The absence of entries in single years could be

${ }^{18}$ Stownik geograficzny Królestwa Polskiego innych krajów słowiańskich, vol. 3, Warszawa 1882, p. 483.

${ }^{19}$ A. Vetulani, "Wartość badawcza ksiąg sądowych wiejskich", in: Pamiętnik VIII Powszechnego Zjazdu Historyków Polskich w Krakowie 14-17 września 1958r., part. 1, Warszawa 1958, p. 205.

${ }^{20}$ There are 31 such years.

${ }^{21}$ P. Guzowski, "Kalendarz gospodarczy i finansowy kmieci polskich na przełomie średniowiecza i czasów wczesno nowożytnych", in: P. Guzowski and M. Liedke (eds.), Człowiek wobec miar i czasu w przeszłości, Kraków 2007, p. 40. 
explained by the lack of legal actions to be recorded or by the inability to bring in a court scribe, in which case the court could make up for overdue records in the following year. However, there are also periods in which the absence of entries in the court roll is due to them not being included in the fair copy of the records (according to many scholars, the original notes were taken on loose sheets of paper or in a makeshift notebook) or due to physical damage to the manuscript. ${ }^{22}$ The other serious fault of court records is the lack of uniformity and consistency in registering cases concerning various social groups constituting the village community. Peasants who performed judicial functions appear in the court records far more frequently than ordinary full-holders. Smallholders and lodgers are mentioned even less frequently. Therefore, some individuals appear in the court rolls only once whereas others are mentioned more than a hundred times. Such disproportions stem from the varying degree of involvement in the village's social life and trading in land. Also women appeared before the court far less frequently than men, making up about $20 \%$ of registered individuals, which could be due to the fact that they hardly ever held the position of household heads. Moreover, women could only appear before the court to assist men - their official guardians or proxies. Comparing the court rolls with other sources concerning villagers would significantly enhance the quality of our research, but unfortunately we do not have any inventories of Trześniowa at our disposal, ${ }^{23}$ and the surviving taxation registers are not detailed enough to allow us to reconstruct the structure of property within the village.

The greatest obstacles, however, result from problems with identification. The turn of the Middle Ages and the early modern era is a period in which surnames were not yet widely used among peasants. In Trześniowa there are several cases which could be interpreted as early examples of surnames, but they are rare. Moreover, court scribes often omitted peasants' nicknames and only gave their first names, which does not facilitate their identification today, especially since the male and female name pools were very limited. It is a very uncomfortable situation from the point of view of a researcher creating a database because it could lead to recording the same person several times. The present demographic analysis was therefore narrowed down to include only individuals listed by name and surname/nickname. Also

${ }^{22}$ For instance in 1420-1426 and 1553-1556.

${ }^{23}$ In contrast to other royal villages, Trześniowa did not occur in any of the several surviving 16th-century inventories of the Sanok land; AGAD, ASK I, 21 pp. 5v-229, pp. 699-895; AGAD, ASK LVI, S. 8, pp. 2v-110, pp. 161-311v. 
the practice of sons-in-law adopting their father-in-law's name proved problematic. The filiations between particular individuals and other direct genealogic data were also rarely written down, which further complicates determining kinship and affinity.

Despite the faults regarding the source that have been listed above, it can be assumed that all men in possession of households sooner or later appeared in court and that their names were registered in the court roll. Since the books contain information about changes in land ownership, they enable the life cycle of full-holder peasants to be observed. Of particular help in this context was the practice of determining the positioning of parcels of land by describing their location in relation to the properties of immediate neighbours, who were mentioned by name. In a strictly demographic context, then, two important issues can be analyzed: the duration of a peasant's economic activity and the size of peasant families. In the latter case, it was possible to genealogically reconstruct the family as well as attempt to reconstruct elements of the marital strategies related to the territorial selection of spouses.

\section{Economic activity of peasants}

In his articles, Andrzej Wyczański attempted to gather data on the activity of the aldermen of village courts, and to this end he selected a group of kmiecie who appeared in the source at least three times. However, to avoid the risk of randomness, and increase the credibility of the results, it seems necessary to modify the criteria for selecting individuals whose life cycle would serve as the basis for the analysis. Therefore, from among the inhabitants of Trześniowa, a group of men was selected who appeared in the court records at least five times. ${ }^{24}$ These conditions were fulfilled by 219 individuals registered in the court roll; most of whom (137 men) appeared in the source for the first and last time in the 16th century, whereas 82 peasants who began (and some of them also ended) their activity in the previous century. In order to minimize the risk of including individuals in the sample whose economic activity began before the earliest court records in Trześniowa were established, as well as peasants who continued their economic activity even though their names no longer appeared in the court roll, the chronological scope of direct observation was limited to the years

\footnotetext{
${ }^{24}$ Under extraordinary conditions, only when it was possible to trace a full-holder's entire land management cycle, people who appeared four times in the book were also taken into account.
} 
1430-1603. This was automatically divided into three sub-periods, thus enabling a simple statistical analysis and observation of the differences between the situation in the late Middle Ages and the beginning of the early modern era (Table 1).

Table 1: Duration of peasants' economic activity in Trześniowa in 1430-1603

\begin{tabular}{c|c|c|c}
\hline Years & Number of people & $\begin{array}{c}\text { Mean duration } \\
\text { of activity }\end{array}$ & $\begin{array}{c}\text { Median of the } \\
\text { duration of activity }\end{array}$ \\
\hline $1430-1500$ & 82 & 25 & 24 \\
\hline $1501-1550$ & 86 & 23.5 & 21 \\
\hline $1551-1603$ & 51 & 21.5 & 20 \\
\hline $1501-1603$ & 137 & 22.8 & 21 \\
\hline $1430-1603$ & 219 & 23.6 & 21 \\
\hline
\end{tabular}

A peasant's first appearance in the source was usually related to his becoming the owner of a plot of land in the village. He was then registered as the buyer or inheritor of the land, or simply as the landowner. More than twenty years usually passed between this moment and his last mention in the court roll. The average duration (mean) of the period of economic activity was 24 , but the median was only 21 , with visible discrepancies between particular sub-periods. Those who remained active the longest (i.e. for almost a quarter of a century) were peasants who started their activity in the 15th century (mean 25 , median -24$)$. A hundred years later the period was several years shorter (mean - 21.5; median - 20).

The varying duration of a peasant's economic activity did not only depend on the chronological aspect but it was also of a social nature. Of the 219 peasants considered full-holders, as many as 130 performed judicial functions in their lifetime, as an aldermen or as the stewards of landlords, thus constituting the village's social, and in all likelihood also the economic, elite (Table 2).

Table 2: Duration of the economic activity of members of Trześniowa's elite in 1430-1603

\begin{tabular}{c|c|c|c}
\hline Years & Number of people & $\begin{array}{c}\text { Mean duration } \\
\text { of activity }\end{array}$ & $\begin{array}{c}\text { Median of the } \\
\text { duration of activity }\end{array}$ \\
\hline $1430-1500$ & 82 & 25 & 24 \\
\hline $1501-1550$ & 86 & 23.5 & 21 \\
\hline $1551-1603$ & 51 & 21.5 & 20 \\
\hline $1501-1603$ & 137 & 22.8 & 21 \\
\hline $1430-1603$ & 219 & 23.6 & 21 \\
\hline
\end{tabular}


The average duration of a member of the elite's economic activity was 26 years (median - 25). At the beginning of the investigated period, it was as much as 27 years (mean 26.6; median 27), decreasing in the 16th century, and amounting to 24.7 (median 22) in the second half of the century. Nevertheless, the values were significantly higher than among peasants who never had any official functions (Table 3).

Table 3: Duration of the economic activity of peasants who never performed official functions in Trześniowa in 1430-1603

\begin{tabular}{c|c|c|c}
\hline Years & Number of people & $\begin{array}{c}\text { Mean duration of } \\
\text { activity }\end{array}$ & $\begin{array}{c}\text { Median of the } \\
\text { duration of activity }\end{array}$ \\
\hline $1430-1500$ & 21 & 20.3 & 19 \\
\hline $1501-1550$ & 38 & 20.6 & 21 \\
\hline $1551-1603$ & 30 & 19.3 & 17.5 \\
\hline $1501-1603$ & 68 & 20 & 19 \\
\hline $1430-1603$ & 89 & 20.1 & 19 \\
\hline
\end{tabular}

The average duration of economic activity in a group of 89 full-holders who did not perform any official functions amounted to 20 years for the entire period investigated (median 19). Slight deviations occur in the following sub-periods, but judging from observations of the arithmetical average, it can be inferred that the differences are not substantial, although the median values for the second half of the 16th century show a noticeable change - a decrease from 21 to 17.5 years.

The figures I have presented raise questions about the reasons for the differences in economic activity between individual peasants throughout the studied period, as well as within the studied sample group. At first glance, these reasons appear to lie within the economic situation that affected the living standards, and in the court rolls themselves. Both factors adequately explain the differences within a sample group of peasants. Members of the rural elite were in a better economic situation and could, therefore, afford better living conditions, and the degree of satisfaction of their biological needs was higher than that of other members of the community. Therefore, they probably lived longer and were economically active for a longer period of time. The fact that they were more economically and socially active must have also resulted in their more frequent appearances on the pages of village court documents, but not only because they simply effected more transactions than other peasants and served regularly as aldermen. Their names were recorded more often because they could afford to pay the fees for the official notes which were entered into the rolls by scribes. 
Given these factors, I am inclined to conclude that the real difference in the duration of economic activity between ordinary peasants and members of the rural elite was less than six years (if we compare the median values for the whole of the period being studied).

More problematic is the explanation for the disproportions in the duration of a peasant's economic activity over a period spanning nearly two centuries. The worsening economic conditions and living standards in the 16th century compared with the late medieval period is not a sufficiently convincing explanation. In fact, historical studies show an improvement both in the macro-economic condition of the country as a whole and in the country's largest social stratum, i.e. the peasantry. Although, in the case of Trześniowa, the taxed acreage decreased from 13 to 9 mansi in the last decades of the 16th century (a 30\% decrease), this was not tantamount to a decrease in the villagers' economic potential. Leasing abandoned farms was then a common practice and it is possible that Trześniowa's peasants also did this, although unfortunately, leases were not recorded in the taxation sources. Other arguments for the village's relatively good economic situation are: (1) the increasing value of land transactions; and (2) the rise in loans taken out by peasants for purchasing land, despite there being a slight fall in the number of such transactions. ${ }^{25}$ The shorter duration of economic activity cannot be explained by the changes in the methods of registration, or the fall in the number of entries in the village court rolls, because the number actually increased in the 16th century, which could be indicative of the greater intensity of economic life in the village.

Having rejected arguments of an economic and formal nature, we could try seeking an explanation for the peasants' shortening duration of economic activity in purely demographic terms. In historiography, the end of the Middle Ages and beginning of the early modern period are perceived as being crucial moments in the creation of the so-called European pattern in marriage. One of the features in this pattern, identified by J. Hajnal, was the relatively advanced age at marriage. ${ }^{26}$ Tine de Moor and Jan van Zenden have recently attempted to explain the origins of this phenomenon. They claimed that the European marriage pattern became widespread in Western Europe after the Black

${ }^{25} \mathrm{P}$. Guzowski, Chłopi i pieniadze na przełomie średniowiecza i czasów nowożytnych, Kraków 2008, pp. 59, 71, 73.

${ }^{26}$ J. Hajnal, "European Marriage in Perspective", in: D.V. Glass and D.E.C. Eversley (eds.), Population in History, London 1965, pp. 101-143; id., "Two kinds of preindustrial household formation system", Population and Development Review, 8, 1982, pp. 449-494. 
Death and was the combined effect of the following three influences: the Catholic Church which propagated the idea of marriage based on the mutual consent of both spouses; an inheritance system which gave women the right to a share in their father's property; and the development of the labour market. ${ }^{27}$ All these elements led to an increase in the age of marriage at the beginning of the early modern period. Due to practical constraints, the present article does not analyze all the conditions facilitating the emergence of the European model of marriage in Central Europe ${ }^{28}$ but it is still worth noting that entering into marriage at a more advanced age than had been the custom one hundred years earlier could have influenced the duration of men's economic activity as the heads of households. The peasants' practice of postponing when they established their own families and, by extension - of becoming independent householders - could have led to their later registration in the court rolls. Thus, the peasants shorter period of economic activity as the owners or managers of allotments did not necessarily denote a shorter life span. This conclusion, however, needs supporting with further research.

\section{Family size}

The information gleaned from the Trześniowa court rolls allowed the reconstruction of 152 families with children. Since women tended to be mentioned less frequently than men in the rolls, the reconstruction of families was based on identifying children's filiation with their fathers. Peasant children appeared in the records under specific circumstances, for example when mentioned as the heirs to their parents' property. In most cases, this occurred on the father's death. In the contemporary inheritance system, all children, both daughters and sons, had a right to equal shares in their parents' farm. In practice, however, only one child took over the property and would then pay off the remaining siblings. ${ }^{29}$

${ }^{27}$ T. de Moor, J.L. van Zanden, "Girl Power. The European Marriage Pattern and Labour Markets in the North Sea Region in the Late Medieval and Early Modern Period", Economic History Review, 62, 2010, pp. 1-33.

${ }^{28}$ P. Guzowski, "Geneza europejskiego modelu małżeństwa na przełomie średniowiecza i czasów wczesnonowożytnych z perspektywy historii Polski”, Przeszłość Demograficzna Polski, 31, 2012, pp. 7-41.

${ }^{29}$ Id., "System dziedziczenia chłopów polskich na przełomie średniowiecza i czasów nowożytnych w świetle sądowych ksiag wiejskich", in: C. Kuklo (ed.), Rodzina i gospodarstwo domowe na ziemiach polskich $w X V-X X$ wieku. Struktury demograficzne, społeczne i gospodarcze, Warszawa 2008, pp. 29-36. 
Such transactions were recorded in the court records, thanks to which it is possible to acquire reliable information about all members of the family eligible for inheritance. Usually, following the death of the head of the household, a so-called "taksa" was conducted, i.e. assessing the value of the property, with a calculation of the amounts the main heir was to pay the siblings. The moment of paying-off such debts began when the heir took over the farm, or later, when a brother or sister got married. The court records registered only those children who lived to the age of majority and appeared in court to claim their share in the inheritance (Table 4).

Table 4: Number of children in reconstructed families registered in the court roll for the village of Trześniowa in 1419-1609

\begin{tabular}{c|c|c|c|c|c}
\hline Years & $\begin{array}{c}\text { Number of } \\
\text { families }\end{array}$ & $\begin{array}{c}\text { Number of } \\
\text { sons }\end{array}$ & $\begin{array}{c}\text { Number of } \\
\text { daughters }\end{array}$ & $\begin{array}{c}\text { Number of } \\
\text { offspring }\end{array}$ & $\begin{array}{c}\text { Average } \\
\text { number of } \\
\text { offspring }\end{array}$ \\
\hline $1419-1500$ & 45 & 61 & 17 & 84 & 1.7 \\
\hline $1501-1550$ & 62 & 105 & 79 & 185 & 3 \\
\hline $1551-1609$ & 45 & 86 & 50 & 139 & 3 \\
\hline $1501-1609$ & 108 & 191 & 129 & 324 & 3 \\
\hline $1419-1609$ & 152 & 252 & 146 & 408 & 2.6 \\
\hline
\end{tabular}

The average number of children registered in the court roll fluctuated throughout the period investigated. In the case of 45 families whose children reached maturity in the 15th century, the arithmetical average was 1.7. In the next century the average rose to 3 children per family. These figures, however, raise doubts. Among the offspring recorded in the court records, there is a stark disproportion in gender, with women being underrepresented. The only explanation appears to be that women simply appeared less frequently in court. As Anna Kamler noted, it is possible that women were more likely to leave their villages than men. Among peasant children, daughters would find husbands outside their villages and some of them never returned to claim their share in the inheritance.

To arrive at more reliable figures, more representative of the demographic reality at the turn of the Middle Ages, we must modify the number of women in order to achieve a balanced proportion of male to female offspring. This can be done by adding the estimated number of daughters. ${ }^{30}$ As we only take into account those children who reached

${ }^{30}$ In his own research Z. Razi took a similar course of action, op. cit., pp. 31, 34. 
the age of majority, we should not use the secondary sex ratio of 105-107 boys to 100 girls at birth, but a sex ratio of 100 to 100 reached at the age of highest fertility (Table 5).

Table 5: Number of children in reconstructed families registered in the court roll for the village of Trześniowa in 1419-1609 after adjustment

\begin{tabular}{c|c|c|c|c|c|c}
\hline Years & $\begin{array}{c}\text { Number } \\
\text { of } \\
\text { families }\end{array}$ & $\begin{array}{c}\text { Number } \\
\text { of } \\
\text { children }\end{array}$ & $\begin{array}{c}\text { Average } \\
\text { number of } \\
\text { children } \\
\text { in the fam- } \\
\text { ily }\end{array}$ & $\begin{array}{c}\text { Number } \\
\text { of added } \\
\text { daughters }\end{array}$ & $\begin{array}{c}\text { Number of } \\
\text { children } \\
\text { after } \\
\text { adjustment }\end{array}$ & $\begin{array}{c}\text { Average } \\
\text { number of } \\
\text { children } \\
\text { after } \\
\text { adjustment }\end{array}$ \\
\hline $1419-1500$ & 45 & 78 & 1.7 & 44 & 122 & 2.7 \\
\hline $1501-1550$ & 62 & 184 & 3 & 26 & 210 & 3.4 \\
\hline $1551-1609$ & 45 & 136 & 3 & 36 & 172 & 3.7 \\
\hline $1501-1609$ & 108 & 320 & 3 & 62 & 382 & 3.6 \\
\hline
\end{tabular}

The results point to diversified family sizes during the investigated period. In the case of 15th-century families, the number of offspring for one reconstructed family was 2.7 . The number gradually increased over the 15th century, reaching as many as 4 children living to adulthood. Given the high death rate among infants, toddlers and young children, resulting in the fact that half of the children died before they reached the age of five ${ }^{31}$ it should be assumed that women in Trześniowa gave birth to 6-8 children on average, which is viable considering natural fertility. The rolls also contain exceptional cases in which parents have eight or even nine children.

The increased number of children reaching adulthood can be explained by two factors: the more detailed nature of 16th-century source materials, and the improvement in living standards, which increased the chances of survival of peasant children. The first factor, i.e. the greater accuracy of court rolls, is apparent in the larger number of registered women. This does not, however, sufficiently explain why the number of surviving children had increased by the end of the 16th century because, as already mentioned, missing daughters were factored into our calculations for earlier periods, and there is no reason to assume that scribes in the earlier periods were less scrupulous about registering male offspring. Men appeared in court as the new owners of purchased or inherited farms, so it was in their best interests to have their cases noted in the rolls. So, it must have been the growing standards of living rather than formal changes in the primary

${ }^{31}$ C. Kuklo, Demografia Rzeczypospolitej przedrozbiorowej, Warszawa 2009, p. 405. 
source that accounted for the higher figure. Unfortunately, it is not possible to provide direct support for this hypothesis because there is a lack of sources describing the economic situation of individual peasants. Nonetheless, we can draw conclusions indirectly from the correspondence between the peasants' social status (stemming from their economic status) and the number of children they had.

The reconstructed families were divided into two similarly numerous social groups - the elite, which included village leaders and aldermen, and the remaining peasants. Observations were also made in terms of the chronological changes (Table 6).

Table 6: Diversification of the number of children in reconstructed families recorded in the court roll for the village of Trześniowa in 1419-1609 based on social status

\begin{tabular}{|c|c|c|c|c|c|c|c|c|c|}
\hline Years & $\begin{array}{l}\text { Social } \\
\text { group }\end{array}$ & 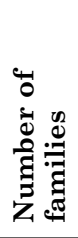 & 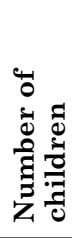 & 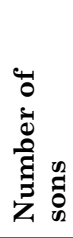 & 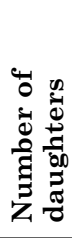 & 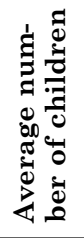 & 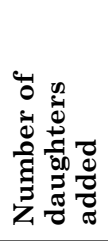 & 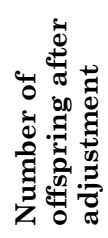 & 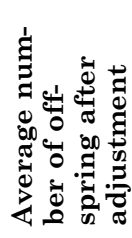 \\
\hline \multirow{2}{*}{$\begin{array}{l}1419- \\
-1500\end{array}$} & Village elite & 21 & 45 & 34 & 11 & 2.1 & 23 & 68 & 3.2 \\
\hline & $\begin{array}{l}\text { Other } \\
\text { peasants }\end{array}$ & 24 & 33 & 27 & 6 & 1.4 & 21 & 54 & 2.2 \\
\hline \multirow{2}{*}{$\begin{array}{l}1501- \\
-1609\end{array}$} & Village elite & 55 & 180 & 111 & 69 & 3.3 & 42 & 222 & 4 \\
\hline & $\begin{array}{l}\text { Other } \\
\text { peasants }\end{array}$ & 52 & 140 & 80 & 60 & 2,7 & 20 & 160 & 3.1 \\
\hline \multirow{2}{*}{$\begin{array}{l}1419- \\
-1609\end{array}$} & Village elite & 76 & 225 & 145 & 80 & 3 & 65 & 290 & 3.8 \\
\hline & $\begin{array}{l}\text { Other } \\
\text { peasants }\end{array}$ & 76 & 173 & 107 & 66 & 2.3 & 41 & 214 & 2.8 \\
\hline
\end{tabular}

The observation of reconstructed families in Trześniowa points to substantial differences in the number of children reaching adulthood in both groups. Throughout the whole of the period of time investigated, among elite families on average 3.8 children reached adulthood, whereas among other peasants it was one child less. Such diversification occurred both in the 15th and 16th centuries, and the improvement in living standards which affected the entire community over a period of nearly 200 years did not reduce the demographic differences.

In this context it is also worth considering the diversification of families in terms of the generation replacement level. Due to deficiencies in the source, it is not possible to calculate the value of this parameter for the whole of Trześniowa's population but only for the group of reconstructed families. The typical demographic net reproduction ratio, 
calculated based on an observation of the female subpopulation, cannot be applied either. Thus the decision was made to calculate how many male heirs of fathers in the reconstructed families reached adulthood and established their own independent households (Table 7).

Table 7: Replacement level among men from reconstructed families

\begin{tabular}{c|l|c|c|c}
\hline Years & Social group & $\begin{array}{c}\text { Number of } \\
\text { fathers }\end{array}$ & Number of sons & $\begin{array}{c}\text { Replacement } \\
\text { level }\end{array}$ \\
\hline \multirow{2}{*}{$1419-1500$} & village elite & 21 & 34 & 1.62 \\
\cline { 2 - 5 } & other peasants & 24 & 27 & 1.13 \\
\hline \multirow{2}{*}{$1501-1609$} & village elite & 55 & 111 & 2.02 \\
\cline { 2 - 5 } & other peasants & 52 & 80 & 1.54 \\
\hline \multirow{2}{*}{$1419-1609$} & Village elite & 76 & 145 & 1.91 \\
\cline { 2 - 5 } & other peasants & 76 & 107 & 1.41 \\
\hline
\end{tabular}

The data obtained indicate that in the late Middle Ages in particular the younger generation barely substituted the older, especially among poorer peasant families. The level of substitution was higher among more affluent peasants, and 16th-century data point to a significant growth in the birth rate, which must have led to substantial migration from the village. From yet another perspective, it should be remembered that the data apply to a rather small group of men that are mentioned in quite a large number of the entries in the court roll. The majority of them belonged to the most active and affluent group among the village community - full-holders. The others - smallholders or lodgers - rarely appeared in the pages of the roll, and both the size of their families and the generational substitution ratio were probably lower than those of the investigated sections of the population.

Identification obstacles do not allow the tracing of either population or migration trends; however, it is possible to explore the issue of the territorial selection of spouses. Thirty-six locations outside Trześniowa were identified in which 76 daughters and sons of Trześniowa families found a spouse, and more importantly, there are no radical differences between the directions chosen by men and women. The largest number of partners came from nearby towns: Brzozowa (11), Jaćmierz (6) and neighbouring villages - Bzianki (11) and Bukowa (6). The geographical scope of migration destinations significantly exceeded the extent of the parish. The inhabitants of Trześniowa married the citizens of towns located at some distance from their family village - marriages were concluded with inhabitants of Sanok (30 km to the east of Trześniowa), 
Bircza (70 km to the east), Jasło (40 km to the west of Trześniowa), Bukowska (30 km to the south), and Pruchnik ( $80 \mathrm{~km}$ to the north).

\section{Conclusions}

This study of the community of Trześniowa is aimed at indicating the directions for future demographic studies into the rural population at the turn of the Middle Ages based on village court rolls. Owing to the specificity of the source, the scope of possible research remains quite limited and allows for only rather general conclusions concerning the demographic conditions of the functioning of peasant families in the 15th and 16th century, with emphasis placed on issues such as the duration of peasants' economic activity, the size of a peasant family, or territorial selection of spouses. These pursuits should definitely be continued, although for the purposes of demographic research only, sources in which the continuity of entries over a longer period of time facilitates basic statistical analysis can be used.

The results obtained confirm rather than undermine the conclusions drawn by Kamler and Wyczański. With regards to family size, it could be stated with more precision that the number of offspring (about 3) denoted children reaching adulthood, while not necessarily providing viable information about women's actual fertility. Moreover, the data gathered for the purposes of this study also appear to support earlier presumptions that there was a close relationship between the size of a family and its social and economic status. This phenomenon was characteristic not only of Poland, as a similar tendency was also observed by Z. Razi in late medieval England. He estimated that an average peasant family which enjoyed the highest financial status had about three children above the age of 12 , the less prosperous had two children, and among the poorest, only 1.4 children survived until the age of majority. ${ }^{32}$ The diversification in the number of offspring could also have affected the structure of households; unfortunately, court rolls do not allow for a reconstruction that would be sufficient

${ }^{32}$ Z. Razi, op. cit., pp. 84, 152. On the other hand, the level of affluence did not have such a visible impact on the number of small children in peasant households registered in the Florence cadastre of 1427, although also here the greater chances for reaching adulthood occurred in richer households - see: D. Herlihy, C. Klapisch-Zuber, Tuscans and their Families. A Study of the Florentine Catasto of 1427, New HaevenLondon 1985, pp. 241-245; D. Herlihy, Medieval Households, Cambridge (Mass.)London 1984, p. 140. 
for statistical analysis. Still, it may well be assumed that in Trześniowa a married couple that managed a larger acreage of land not only had more children, but also a larger household. We can only guess that Trześniowa did not differ dramatically in this respect from other places. As we learn from the works of M. Kopczyński, ${ }^{33}$ M. Górny ${ }^{34}$ and Z. Kwaśny ${ }^{35}$ in 17 th-century Royal Prussia and 18th-century Kuyavia and Wieluński county, ${ }^{36}$ in the Pępowo parish in Greater Poland, and in Silesia, couples who owned larger amounts of land, not only had more children but also larger households.

The twenty years of economic activity of Trześniowa's peasants was longer than the figure calculated by Andrzej Wyczański, but it does not make the bulk of his findings invalid. We have no direct information about the age at which people in the 15th and 16th centuries got married, but if we assume there was no noticeable difference between the situation in these and the following centuries, when the average age of marriage was from 24 to $30,{ }^{37}$ some fathers did not live to see their children reach maturity, establish families, create separate households, and farm their own land. This had very far-reaching social and economic consequences. First of all, it confirms that the decision about whom to marry was made by the interested parties themselves rather than by their parents. It may be true then that peasants were more likely to marry for love than were representatives of groups which were higher placed in the social hierarchy. Although it is difficult to measure statistically the degree of endogeneity of marriages, when we look at the geographical origins of the spouses of Trześniowa's inhabitants, we can see that the parish borders did not delimit their social contacts. The general trend was that if a marriage partner came from a rural settlement, it was either Trześniowa itself or a neighbouring village within the same parish; ${ }^{38}$ if a spouse came from a town, it was usually a much more distant place. G. Jawor noted that in the area

${ }^{33}$ M. Kopczyński, Studia nad rodzina chtopska $w$ Koronie $w$ XVI-XVIII wieku, Warszawa 1998, pp. 50, 94.

${ }^{34}$ M. Górny, Mieszkańcy parafii pepowskiej w 1777 roku. Analiza księgi status animarum, Wrocław 1994, p. 19.

${ }^{35}$ Z. Kwaśny, Rodzina chtopska w parafii Dobra w latach 1727-1758, in: H. Suchojad (ed.), Wesela, chrzciny i pogrzeby $w$ XVI-XVIII $w$. Kultura życia $i$ śmierci, Warszawa 2001, p. 30.

${ }^{36}$ M. Kopczyński, op. cit., pp. 50, 94.

${ }^{37}$ C. Kuklo, op. cit., p. 279.

${ }^{38}$ G. Jawor, "Obraz rodziny chłopskiej Polsce XV wieku w świetle ksiag oficjała lubelskiego", Annales Universitatis Mariae Curie-Sktodowska. Sectio F. Historia, 41/42, 1986/1987, p. 83. 
under the jurisdiction of the bishop's court in Lublin, in the majority of cases, peasant sons and daughters who married outside their villages migrated to the largest urban centre, i.e. Lublin, which attracted peasants from an area within an 18-kilometre radius of the city. ${ }^{39}$ The sons and daughters from Trześniowa, in contrast, migrated to a number of smaller towns scattered all over the Sanok region. It is also worth adding that we do not find any direct evidence in the rolls that village landlords attempted in any way to limit their peasants' freedom to marry outside Trześniowa. It appears wrong to assume, as was the case previously, that in the borderlands of Little Poland and Red Ruthenia at the turn of the Middle Ages, landlords exercised the same influence over their peasants' decisions concerning marriage and households as in the 18th century. ${ }^{40}$ This, of course, does not preclude, landlords' interest in maintaining the continuity of peasant households. As we learn from the demographic analysis of Trześniowa court rolls, the problem was that the periods of the peasants' economic activity were too short, as Andrzej Wyczański claimed, to avoid the occurrence of 'empty farms'. If landlords respected that children had a right to their fathers' inheritance, the time between a father's death and the moment his adult and independent (and most probably also married) son took over the farm, was the time when there was a risk that the farm would not bring profits to the lord and would not provide maintenance for a widow and her children. The question of whether such risk was very high still remains unanswered and requires further research which could be based on inventories which were available in greater abundance from the 16th century onwards.

Piotr Guzowski

Demographic conditions of the functioning of peasant families at the turn of the Middle Ages

(Summary)

The main aim of this paper is to present the possibilities of applying judicial sources to a demographic analysis of 15th- and 16th-century peasant families. The appearance of village court records is connected with the promulgation of German law on Polish lands and the emergence of the institution of local gov-

${ }^{39}$ Ibid., p. 84.

${ }^{40}$ W. Kula, Teoria ekonomiczna ustroju feudalnego, Warszawa 1983, pp. 233-245;

A. Woźniak, Kultura mazowieckiej wsi pańszczyźnianej, Warszawa 1987, pp. 71ff. 
ernment headed by the bailiff, who together with peasant aldermen performed judicial duties. Over $70 \%$ of the village court records deal with the land market, rents, wills, matters of inheritance, loans and liens, criminal and moral cases, and disputes among neighbours.

The subject of study in the present article is one of the oldest Polish village court records from the village of Trześniowa, 1409-1609, published by Helena Polaczkówna. The study focuses on three problems: the duration of the peasants' economic activity, the size of families and territorial selection of spouses.

The average duration (mean) for the investigated period was 24 years but the median was only 21 , with visible discrepancies between particular subperiods. Peasants who remained active the longest were those who began their activity in the 15 th century (mean -25 , median -24 ). One hundred years later, this period was several years shorter (mean - 21.5; median - 20). The variations in the durations of peasants' economic activity can also be observed in the social dimension. The average duration of the economic activity of members of the peasant elite (bailiffs, aldermen) amounted to 26 years (median 25) and was significantly higher than among peasants who never performed any official functions.

The average number of children registered in the court roll fluctuated throughout the period under investigation. In the case of 45 families whose children reached maturity in the 15th century, the mean was 1.7 . In the following century the average rose to 3 children per family. However, among the offspring recorded in the court records there was a marked disproportion regarding gender, to the advantage of men, so women who are missing in the source should be added in order to achieve a balance. The observation of the reconstructed families in Trześniowa points to substantial differences in the number of children reaching adulthood in both groups of the peasant population. Throughout the entire investigated time period, in elite families the average number of children reaching adulthood amounted to 3.8 whereas among other peasants it was one child less.

Trześniowa's inhabitants married citizens of towns located at some distance from their family village - marriages were concluded with people living within $80 \mathrm{~km}$ of Trześniowa.

Key w ord s: peasant family, historical demography, peasant economic activity, village court records 